DOI: https://doi.org/10.47405/mjssh.v6i12.1181

\begin{tabular}{|c|c|}
\hline & Malaysian Journal of Social Sciences and Humanities (MJSSH) \\
\hline Malaysian Journa of & Volume 6, Issue 12, December 2021 \\
\hline (Mus. SSH) & e-ISSN : 2504-8562 \\
\hline & $\begin{array}{l}\text { Journal home page: } \\
\text { www.msocialsciences.com }\end{array}$ \\
\hline
\end{tabular}

\title{
Persepsi Guru Matematik Sekolah Rendah Terhadap Pengajaran Konseptual Atau Prosedural
}

\author{
Ahmad Mustafa bin Mahmud', Muhammad Sofwan Mahmud \\ 1Fakulti Pendidikan, Universiti Kebangsaan Malaysia (UKM), Malaysia \\ Correspondence: Ahmad Mustafa bin Mahmud (ahmadmustafamahmud@gmail.com)
}

\begin{abstract}
Abstrak
Kajian gabungan kualitatif dan kuantitatif yang dilaksanakan ini adalah untuk meninjau persepsi guru matematik sekolah rendah terhadap pengajaran bersifat konseptual atau prosedural. Pengkaji menggunakan kaedah pemerhatian semasa proses pengajaran dan pembelajaran berjalan. Kajian ini juga meninjau dengan menggunakan borang kaji selidik berskala Likert 5 pandangan guru matematik sekolah rendah terhadap pengajaran bersifat konseptual atau prosedural. Peserta dalam kajian ini ialah 5 orang guru matematik sekolah rendah. Kajian ini bertujuan untuk menjawab dua persoalan kajian iaitu, apakah pengajaran guru matematik sekolah rendah dalam proses pengajaran dan pembelajaran bersifat konseptual atau prosedural? Persoalan kedua ialah apakah pandangan guru matematik sekolah rendah terhadap pendekatan-pendekatan konseptual dalam pengajaran matematik? Dapatan kajian menunjukkan semua peserta kajian dilihat jelas mengaplikasikan pendekatan prosedural. Dapatan kajian juga menunjukkan peserta kajian bersetuju pada tahap tinggi (min skor 4.08) berkaitan kepentingan pendekatan-pendekatan bersifat konseptual. Mereka juga bersetuju pada tahap tinggi (min skor 3.9) tentang wujudnya kebaikan dan keburukan pendekatan-pendekatan bersifat prosedural. Akhir sekali, semua peserta kajian bersetuju pada tahap sederhana (min skor 3.65) berkaitan sikap terhadap pelaksanaan pendekatan-pendekatan bersifat konseptual dan prosedural.
\end{abstract}

Kata kunci: pengajaran, pendekatan, konseptual, prosedural

\section{Primary School Mathematics Teachers' Perceptions of Conceptual or Procedural Teaching}

\begin{abstract}
This combined qualitative and quantitative study was conducted to survey the perception of primary school mathematics teachers on teaching of a conceptual or procedural nature. Researchers use observation methods during the teaching and learning process. This study also examines using a Likert -scale survey form 5 the views of primary school mathematics teachers on teaching of a conceptual or procedural nature. The participants in this study were 5 primary school mathematics teachers. This study aims to answer two research questions, namely, is the teaching of primary school mathematics teachers in the teaching and learning process conceptual or procedural? The second question is what are the views of primary school mathematics teachers on conceptual approaches in mathematics teaching? The findings of the study showed that all the participants of the study were clearly seen to apply the procedural approach. The findings of the study also showed that the participants agreed at a high level (mean score 4.08) regarding the importance of conceptual approaches. They also agreed at a high level (mean score 3.9) about the existence of pros and cons of procedural approaches. Finally, all
\end{abstract}


study participants agreed at a moderate level (mean score 3.65) regarding attitudes towards the implementation of conceptual and procedural approaches.

Keywords: teaching, approaches, conceptual, procedural

\section{Pengenalan}

Pengajaran dan pembelajaran yang berfokus kepada penyampaian konsep adalah satu pendekatan yang perlu diberi perhatian untuk membina tahap penguasaan murid yang baik terhadap semua kemahiran dalam subjek Matematik tidak kira di sekolah rendah atau menengah. Beberapa pendekatan, kaedah dan teknik digunakan dalam pendekatan konseptual iaitu konstruktivisme, pembelajaran kontekstual, pembelajaran koperatif, pembelajaran masteri dan inkuiri penemuan (Kurikulum, 2019). Kaedahkaedah ini dapat membantu menyediakan murid untuk membina pemahaman yang kukuh, membina dan memahami konsep matematik dengan berkesan. Sekolah rendah merupakan medan pertama anakanak kecil membina asas kemahiran matematik untuk di bawa ke peringkat sekolah menengah, peringkat universiti dan seterusnya diaplikasikan dalam kehidupan seharian. Justeru, proses pengajaran dan pembelajaran matematik di sekolah rendah wajar menggunakan pendekatan-pendekatan yang berupaya membina asas kefahaman dan penguasaan kemahiran asas matematik yang berkesan di kalangan murid.

Guru-guru matematik di sekolah rendah wajar melaksanakan pengajaran dan pembelajaran yang bersifat konseptual agar murid-murid menguasai konsep kemahiran matematik dengan baik. Fallis (2013) menyatakan jika kaedah dan cara pendekatan yang sesuai dapat digunakan, maka mata pelajaran Matematik akan lebih mudah dikuasai dan kemahiran tertentu akan dapat dikembangkan. Salah satu langkah yang penting untuk meningkatkan kecekapan dalam kemahiran matematik ialah menekankan kefahaman dan penguasaan konsep matematik di kalangan murid. Ini membuktikan bahawa pendekatan bersifat konseptual wajar dilaksanakan oleh guru sama ada di dalam atau di luar bilik darjah untuk memberi impak yang berkesan terhadap pengajaran dan pembelajaran matematik.

\section{Pernyataan Masalah}

Kajian-kajian lepas mendapati masalah pembelajaran matematik bermula daripada dalam bilik darjah, iaitu melibatkan persoalan, kaedah dan strategi pengajaran serta bagaimana kaedah murid memahami konsep matematik yang dipelajari. Pengajaran guru juga menjadi persoalan utama yang diperbincangkan pada semua peringkat (Zainal, 2008). Bahagian Pembangunan Kurikulum bagi semua peringkat telah mencadangkan kaedah serta pendekatan yang relevan dilaksanakan di bilik darjah dalam pengajaran dan pembelajaran matematik (Kurikulum, 2019). Kelima-lima pendekatan tersebut iaitu konstruktivisme, pembelajaran kontekstual, pembelajaran koperatif, pembelajaran masteri dan inkuiri penemuan adalah bersifat konseptual. Kaedah-kaedah yang terkandung dalam pendekatanpendekatan tersebut berupaya membantu membina konsep matematik secara berkesan dan menjadikan proses pengajaran dan pembelajaran matematik yang lebih bermakna.

Permasalahan di sini ialah pembelajaran matematik di kalangan murid di sekolah rendah adalah secara instrumental atau secara 'spoon feed'. Ciri-ciri utama dalam kaedah pembelajaran ini bergantung kepada keupayaan untuk menghafal fakta-fakta arbitari, berbeza dengan pembelajaran bermakna atau pembelajaran bersifat relasional hanya terjadi apabila fakta dan idea diletakkan dalam struktur yang koheren (Adnan et al. 2014). Kaedah menghafal peraturan dan prosedur untuk menyelesaikan masalah bukan teknik terbaik untuk menguasai konsep pembelajaran (Tengku Zainal et al., 2009). Namun begitu, tidak dinafikan bahawa pengajaran berasaskan prosedural mempunyai kelebihan tersendiri iaitu mudah diikuti dan memberi kesan dengan pantas serta jelas dilihat oleh murid. Pada kebiasaannya, murid akan berupaya menjawab soalan dan menulis jawapan dengan betul dan pantas dalam latihanlatihan yang disediakan oleh guru. 
Walau bagaimanapun, pengajaran dan pembelajaran yang menggunakan kaedah dan pendekatan yang sesuai dan berkesan merupakan aspek utama bagi seorang guru matematik. Pendekatan yang paling bermakna adalah sekiranya guru matematik berupaya menggabungkan pendekatan konseptual dan prosedural dalam pengajaran dan pembelajaran. Kesannya, murid akan memperoleh kedua-dua kelebihan pendekatan konseptual dan prosedural bersama. Menurut Sonia (2000), guru wajar melaksanakan pendekatan konseptual semasa pengajaran, melaksanakan pengajaran berteraskan hierarki atau konflik kognitif dan melaksanakan pengajaran dan pembelajaran bersifat relasional, iaitu menghubungkaitkan kemahiran matematik dengan kehidupan sebenar.

\section{Objektif Kajian}

Kajian ini dijalankan untuk:

i. Mengenal pasti pengajaran guru matematik yang dilaksanakan di sekolah rendah sama ada bersifat konseptual atau prosedural.

ii. Meninjau pandangan guru matematik sekolah rendah terhadap pendekatan-pendekatan bersifat konseptual dalam pengajaran matematik.

\section{Sorotan Literatur}

Pengetahuan konseptual dan prosedural diperlukan dalam pembelajaran dan menyelesaikan masalah matematik. Abidin (2012) menyatakan bahawa pengetahuan konseptual yang tidak didukung oleh oleh pengetahuan prosedural akan menyebabkan murid menguasai konsep tetapi murid tidak mampu menyelesaikan masalah matematik. Talib (2017) pula menyatakan pengetahuan prosedural yang tidak didukung oleh pengetahuan konseptual akan menyebabkan murid berupaya membuat kiraan tetapi tidak memahami dan mengetahui konsep pengiraan tersebut. Ini bermaksud murid sekadar menghafal kaedah pengiraan tetapi apabila nombor atau masalah di ubah, murid sukar untuk menyelesaikan soalan tersebut. Leong et al. (2020) menyatakan pemahaman murid dalam konsep matematik akan membantu murid menguasai dan mengaplikasikan ilmu matematik yang dipelajari dengan baik dan berkesan.

Pemahaman konseptual adalah keupayaan seseorang untuk membuat perkaitan satu idea matematik dengan idea matematik yang lain, perkaitan dengan soalan yang lain dan berupaya untuk menyatakan contoh (Adnan \& Zakaria, 2012). Kenyataan ini bermaksud pemahaman konseptual adalah kefahaman untuk menghubungkan konsep-konsep matematik untuk menyelesaikan masalah matematik. Namun, pengajaran matematik di dalam kelas lebih tertumpu kepada pemahaman proses atau prosedural dan tidak memberi penekanan kepada pengetahuan konseptual (Zakaria, 2007). Kebanyakan murid Malaysia menghafal rumus matematik untuk menyelesaikan masalah matematik tanpa menguasainya dengan betul (Tan, 2018). Menurut Teng, Mohd Tajudin dan Masri (2017), penghafalan rumus matematik tanpa penguasaan dengan betul tidak membantu dalam pemahaman konsep pengetahuan murid.

Kefahaman konsep matematik diperoleh secara pembelajaran bermakna atau konseptual. Menurut Yusof et al. (2016), hasil kefahaman ini akan membawa murid mencapai satu tahap iaitu mereka berupaya untuk memahami konsep-konsep yang menjadi asas kaedah-kaedah yang dipelajari. Kefahaman prosedural ini dikenali sebagai operational, instrumental dan role learning. Kefahaman matematik secara prosedural adalah menjurus kepada murid menghafal prosedur dan kaedah menyelesaikan masalah matematik (Adnan et al., 2014). Seterusnya, apabila murid menemui masalah baru, mereka akan mempelajari dan menghafal kaedah baru untuk menyelesaikan masalah tersebut. Berbeza dengan kefahaman konseptual yang melatih murid untuk memahami kaedah penyelesaian sesuatu masalah dan hasilnya membolehkan mereka untuk membuat perkaitan kaedah tersebut dengan masalah baru. Kefahaman konseptual tampak sukar untuk difahami dan dikuasai oleh murid namun, ia memberi impak yang sangat berguna kepada murid dalam penyelesaian masalah baru dengan mudah setelah difahami dan dikuasai. 
Menurut Yahaya (2018), kefahaman secara prosedural mungkin mendatangkan kesan yang tidak diingini dalam pembelajaran matematik murid dan berupaya menimbulkan masalah seperti murid mencipta hukum, peraturan dan kaedah mereka sendiri yang lebih bermakna berbanding dengan ilmu yang telah diajar oleh guru. Guru lebih cenderung untuk menggunakan kaedah prosedural yang mempunyai kekuatan dan mudah untuk diajar kepada murid namun untuk jangka masa panjang, proses pengajaran dan pembelajaran akan menjadi kurang bermakna.

Ismail \& Junita (2018) dalam kajiannya menceritakan Cikgu Mohd Ab Rahman bin Ibrahim semasa melaksanakan proses pengajaran dan pembelajaran untuk menerangkan konsep isi padu gabungan kubus dan kuboid telah menggunakan pendekatan permainan Bingo dan Lego. Aktiviti berkumpulan ini secara tidak langsung telah mempraktikkan pendekatan konstruktivisme kerana murid telah membina model gabungan kubus dan kuboid mereka sendiri. Kemudian, mereka sendiri membina konsep isi padu gabungan bongkah berkenaan daripada model yang dibina itu (Sazali, Sajap \& Azhar, 2018). Konstruktivisme menekankan bahawa setiap manusia mempelajari sesuatu dan memperoleh pengetahuan melalui hasil mentalnya. Pendekatan ini menumpukan kepada usaha murid untuk belajar, menjana dan menguji pengetahuan yang diperoleh.

Seseorang pendidik wajar memainkan peranan yang penting dalam menyampaikan sesuatu maklumat secara berkesan kepada murid agar murid dapat memahami dan seterusnya menyimpan maklumat tersebut untuk jangka masa panjang (Yahaya, 2018). Oleh itu, pembelajaran berbentuk pemahaman konsep diperlukan untuk meningkatkan daya ingatan murid, menyelesaikan masalah matematik dan mengaplikasikannya dalam kehidupan seharian. Mulyono et al. (2018) menyatakan penguasaan konsep yang baik dalam pemikiran murid harus diwujudkan dan ia tidak akan hadir dengan sendirinya. Justeru, peranan guru adalah untuk membantu pembentukan proses kefahaman konsep matematik tersebut.

\section{Metod Kajian}

\section{Reka Bentuk Kajian}

Kajian ini menggunakan reka bentuk gabungan kualitatif dan kuantitatif (exploratory sequential mixed methods design) yang bertujuan untuk menjawab dua soalan kajian. Pengkaji hadir semasa proses pengajaran dan pembelajaran peserta kajian yang dipilih dan melaksanakan pemerhatian secara dekat dalam mengumpul data secara kualitatif. Pemerhatian yang dilaksanakan bagi membolehkan pengkaji melihat sendiri apakah pengajaran yang digunakan oleh peserta kajian dalam pengajaran dan pembelajaran mereka, sama ada bersifat konseptual atau prosedural? Pengkaji akan merakamkan gambar dan menjalankan sesi temu bual tidak berstruktur semasa sesi pemerhatian. Pengkaji seterusnya menganalisis dapatan yang diperoleh berdasarkan senarai semak jenis-jenis pengajaran yang bersifat konseptual dan prosedural.

Seterusnya, pengkaji menyediakan borang kaji selidik untuk meninjau pandangan peserta kajian terhadap pendekatan-pendekatan bersifat konseptual dalam pengajaran dan pembelajaran matematik. Borang kaji selidik menggunakan Skala Likert 5 mata, iaitu $1=$ sangat tidak pasti, $2=$ tidak pasti, $3=$ kurang pasti, 4 = pasti, $5=$ sangat pasti. Tafsirannya adalah seperti di dalam Jadual 1 berikut:

Jadual 1: Pecahan Skala Likert

\begin{tabular}{lll}
\hline \multicolumn{1}{c}{ Skala } & \multicolumn{1}{c}{ Takrifan } \\
\hline 1. Sangat tidak pasti & $\begin{array}{l}\text { Peserta kajian tidak bersetuju langsung } \\
\text { mengenai perkara yang dinyatakan } \\
\text { Peserta kajian tidak bersetuju mengenai perkara } \\
\text { yang dinyatakan }\end{array}$ \\
2. Tidak pasti & $\begin{array}{l}\text { Peserta kajian bersetuju mengenai perkara yang } \\
\text { dinyatakan tetapi kurang pasti }\end{array}$ \\
3. Kurang pasti & $\begin{array}{l}\text { Peserta kajian bersetuju mengenai perkara yang } \\
\text { dinyatakan }\end{array}$ \\
4. Pasti &
\end{tabular}



DOI: https://doi.org/10.47405/mjssh.v6i12.1181

\begin{tabular}{ll} 
5. Sangat pasti & $\begin{array}{l}\text { Peserta kajian sangat bersetuju mengenai } \\
\text { perkara yang dinyatakan }\end{array}$ \\
\hline
\end{tabular}

Manakala takrifan skor min pula adalah seperti di dalam Jadual 2 berikut:

Jadual 2: Pecahan Skor Min

\begin{tabular}{|c|c|}
\hline Skor Min & Tahap \\
\hline $1.00-2.33$ & Tidak setuju (Rendah) \\
\hline $2.34-3.66$ & Setuju (Sederhana) \\
\hline $3.67-5.00$ & Sangat bersetuju (Tinggi) \\
\hline
\end{tabular}

\section{Reka Bentuk Kajian}

Peserta kajian adalah terdiri daripada 5 orang guru matematik sekolah rendah di sebuah daerah di Negeri Sembilan. Pemilihan peserta kajian adalah berdasarkan daripada perbincangan bersama Pegawai SISC+ Matematik Pejabat Pendidikan Daerah dan seterusnya kesediaan guru-guru berkenaan melibatkan diri sebagai peserta kajian. Pengkaji menggunakan teknik persampelan bertujuan sebagai pemilihan peserta kajian. Menurut Mohd Rusdin \& Dollah (2018), teknik persampelan bertujuan memberikan gambaran yang relevan dengan soalan serta tajuk kajian. Apabila teknik persampelan bertujuan digunakan, pengkaji bebas menentukan bilangan peserta kajian yang dipilih (Salleh 2016). Justeru, pengkaji berpendapat 5 orang guru yang dipilih adalah sesuai dalam kajian ini berbanding dengan saiz kajian. Latar belakang peserta kajian adalah seperti di dalam Jadual 3 berikut:

Jadual 3: Latar Belakang Peserta Kajian

\begin{tabular}{ccccccc}
\hline Bil & Kriteria Guru & R1 & R2 & R3 & R4 & R5 \\
\hline 1. & Opsyen matematik & $/$ & X & $/$ & $/$ & X \\
\hline 2. & PPP Siswazah & $/$ & $/$ & $X$ & $/$ & $/$ \\
3. & $\begin{array}{c}\text { Berpengalaman } \\
\text { mengajar matematik } \\
\text { lebih daripada 5 tahun } \\
\text { Mengajar matematik } \\
\text { murid tahap 1 dan 2 }\end{array}$ & X & $/$ & $/$ & $/$ & X \\
4. & $/$ & X & $/$ & $/$ & X \\
5. & $\begin{array}{c}\text { Berminat mengajar } \\
\text { matematik }\end{array}$ & $/$ & $/$ & $/$ & $/$ \\
6. & Jenis sekolah & SK & SK & SJK $(C)$ & SK & SJK(T) \\
\hline
\end{tabular}

Kata kunci: $\mathrm{R}=$ Peserta kajian, $\mathrm{SK}=$ Sekolah Kebangsaan, SJK(C) = Sekolah Jenis Kebangsaan Cina, $\operatorname{SJK}(\mathrm{T})=$ Sekolah Jenis Kebangsaan Tamil

\section{Hasil Kajian}

Pengkaji membuat catatan, mengambil gambar dan merakam temu bual yang dijalankan sewaktu membuat pemerhatian terhadap proses pengajaran dan pembelajaran peserta kajian untuk menjawab soalan kajian 1. Pengkaji menyediakan catatan kerja lapangan bagi memudahkan proses mencatat segala maklumat yang diperoleh. Pengkaji juga menyediakan transkrip bagi melancarkan sesi temu bual yang dilaksanakan dalam kajian ini. Seterusnya, bagi menjamin kesahan dapatan kajian ini, pengkaji menggunakan khidmat seorang pengkaji lain untuk menyemak analisis yang telah dijalankan. Pengkaji menganalisis data dengan gambar yang diambil dan disokong oleh temu bual tidak berstruktur yang dijalankan.

Pengkaji menggunakan borang kaji selidik berskala likert 5 (positif) untuk mengutip data dan seterusnya menjawab soalan kajian 2. Pengkaji menganalisis data ini secara manual untuk mencari min skor kajian. Akhir sekali, pengkaji membuat perhubungan hasil analisis data yang diperoleh dengan sorotan literatur untuk membuat rumusan bagi peserta kajian. 


\section{Pengajaran Guru Matematik Sekolah Rendah}

Berdasarkan pemerhatian yang telah dijalankan, pengkaji mendapati semua peserta kajian melaksanakan proses pengajaran dan pembelajaran dengan menggunakan pengajaran yang bersifat prosedural. Kesemua peserta kajian jelas tidak menerapkan pendekatan-pendekatan yang bersifat konseptual iaitu konstruktivisme, kontekstual, pembelajaran koperatif, inkuiri penemuan dan pembelajaran masteri. Sebagai contoh, Peserta Kajian 1 melaksanakan proses pengajaran dan pembelajaran yang berpusatkan guru, di mana guru menunjukkan beberapa contoh masalah kepada murid. Seterusnya, guru sendiri menerangkan cara menyelesaikan masalah-masalah tersebut kepada murid di hadapan kelas seperti yang ditunjukkan dalam Rajah 1 di bawah.

\section{Rajah 1: Sesi Pengajaran oleh Peserta Kajian 1}

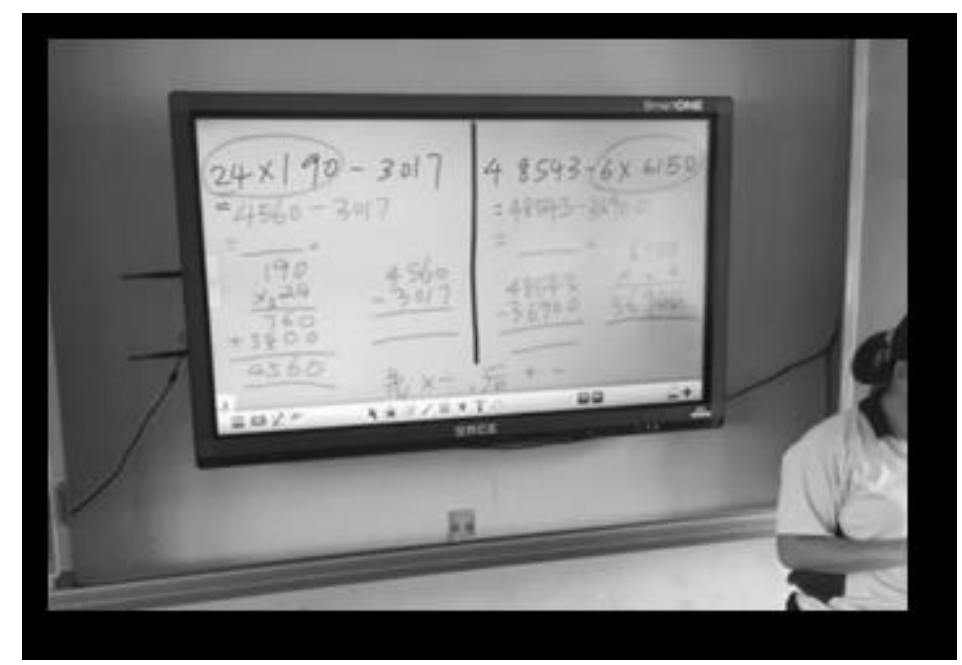

Pengkaji membuat pemerhatian terhadap proses pengajaran dan pembelajaran Peserta Kajian 1 pada sesi yang lain dan mendapati murid menjalankan aktiviti penyelesaian masalah secara berkumpulan. Didapati murid-murid Peserta Kajian 1 terikat dengan prosedur penyelesaian masalah seperti yang diterangkan oleh guru dalam kelas sesi sebelum ini walaupun aktiviti berkumpulan dilaksanakan seperti yang ditunjukkan dalam Rajah 2 di bawah.

Rajah 2: Aktiviti Penyelesaian Masalah Secara Berkumpulan

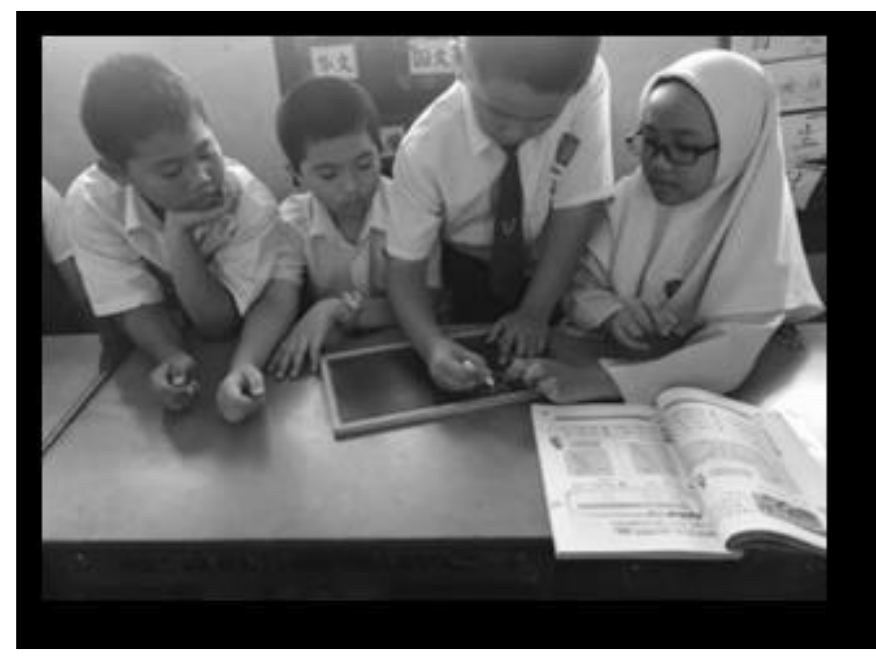

Proses pengajaran dan pembelajaran berpusatkan guru adalah tidak memenuhi ciri-ciri pengajaran yang bersifat konseptual. Sebaliknya ia diklasifikasikan sebagai pengajaran bersifat prosedural. 
DOI: https://doi.org/10.47405/mjssh.v6i12.1181

Pengkaji mendapati Peserta Kajian 2 menerapkan pengajaran matematik yang bersifat prosedural. Semasa proses pengajaran dan pembelajaran dijalankan, Peserta Kajian 2 turut sama menjalankan aktiviti berkumpulan. Namun begitu, murid-murid dilihat menyelesaikan masalah yang diberikan oleh guru dengan mengingat semula kaedah penyelesaian yang telah dihafal hasil penerangan yang disampaikan oleh guru seperti yang ditunjukkan dalam Rajah 3 di bawah.

\section{Rajah 3: Proses Pengajaran dan Pembelajaran oleh Peserta Kajian 2}

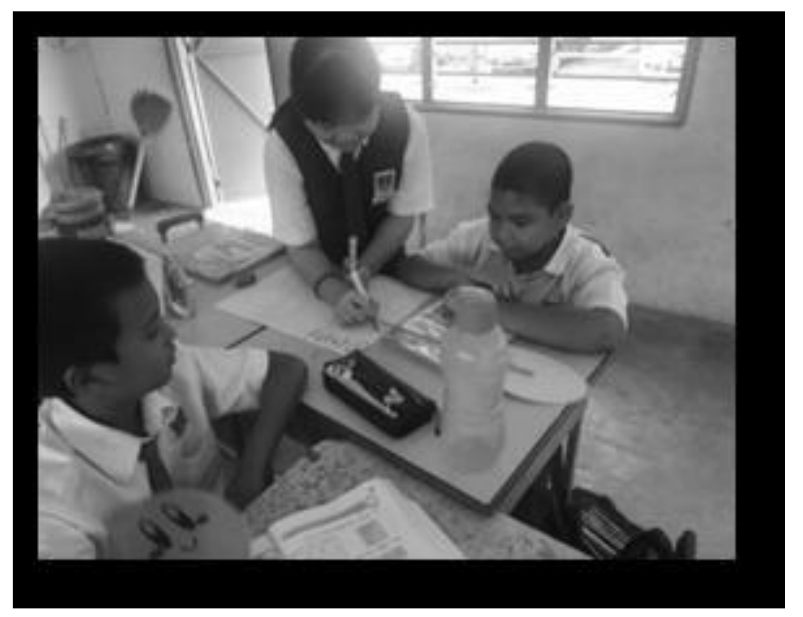

Pengkaji dapat memerhatikan murid-murid Peserta Kajian 3 menghafal prosedur penyelesaian operasi tolak seperti yang ditunjukkan oleh guru mereka. Jelas murid-murid ini tidak memahami konsep penyelesaian operasi tolak yang betul. Rajah 4 di bawah menunjukkan contoh penyelesaian operasi tolak yang digunakan oleh Peserta Kajian 3:

Rajah 4: Penyelesaian Operasi oleh Peserta Kajian 3

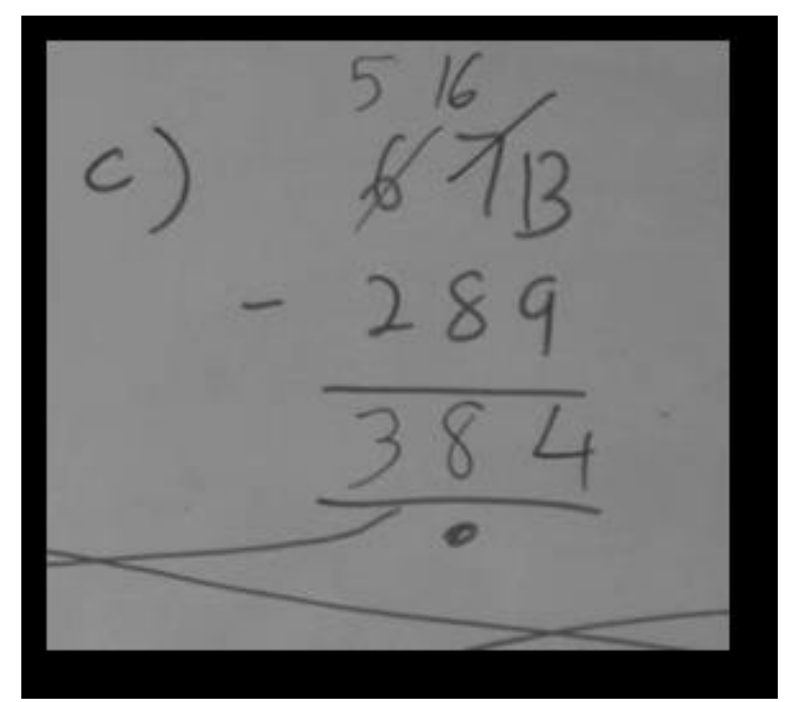

Pengkaji telah menemu bual seorang murid di dalam kelas Peserta Kajian 3 berkaitan penyelesaian operasi tolak dalam rajah di atas:

$\begin{array}{lll}\text { Pengkaji } & : & \text { Kenapa kamu pinjam dari angka } 7 \text { di sebelah? } \\ \text { Murid 1 } & : & \text { Angka } 3 \text { tu lebih kecil daripada 9. Tak boleh la saya nak tolakkan. } \\ \text { Pengkaji } & : & \text { Berapa nilai yang kamu pinjam dari angka } 7 \text { di sebelah tu? } \\ \text { Murid 1 } & : & 1 . \\ \text { Pengkaji } & : & \text { 1 sahaja? } \\ \text { Murid 1 } & : & \text { Betul cikgu. 1 sahaja. } \\ \text { Pengkaji } & : & \text { Bukan } 10 \text { ke? }\end{array}$


DOI: https://doi.org/10.47405/mjssh.v6i12.1181

Murid 1 : $\quad$ Tidak. 1 sahaja. Bila saya letak sebelah 3 tu, jadi la 13. Baru boleh tolak dengan 9.

Semasa aktiviti membuat latihan di dalam buku tulis, pengkaji mendapati murid-murid lain turut membuat pengiraan tolak sejajar dengan penerangan dan contoh yang ditunjukkan oleh guru mereka.

Peserta Kajian 4 melaksanakan pendekatan 'chalk and talk' ketika sesi pengajaran dan pembelajaran. Murid-murid hanya duduk di tempat masing-masing memerhatikan dan mendengar penerangan yang disampaikan oleh guru tentang menyelesaikan operasi darab. Peserta Kajian 4 menerangkan kaedah mendarab dengan mengumpul semula langkah demi langkah dan seterusnya murid-murid membuat latihan secara individu untuk meningkatkan kefahaman murid seperti yang ditunjukkan dalam Rajah 5 di bawah. Semasa membuat latihan secara individu, pengkaji dapat memerhatikan murid-murid Peserta Kajian 4 ini menjawab soalan darab dengan menggunakan kaedah yang sama seperti ditunjukkan oleh guru mereka.

\section{Rajah 5: Sesi Penerangan oleh Peserta Kajian 4}

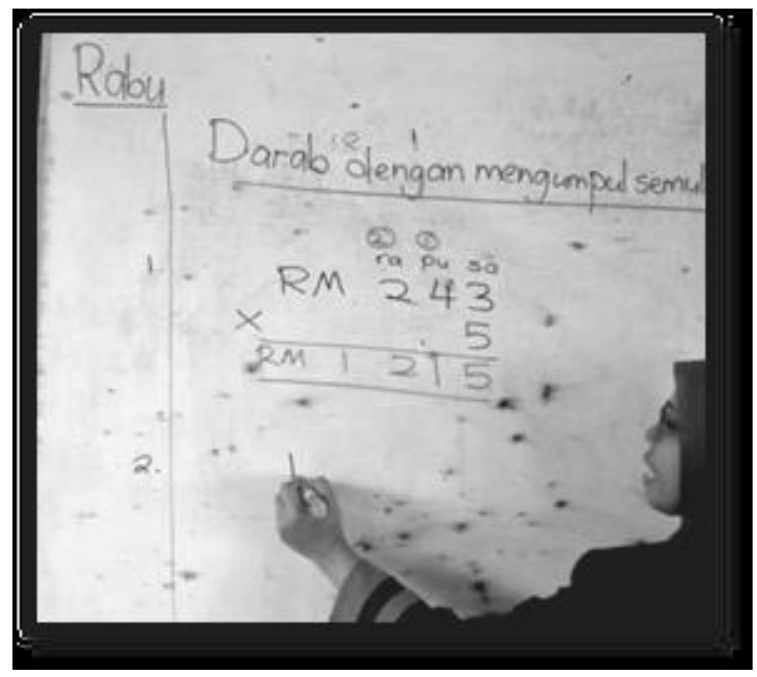

Pengkaji tertarik dengan pendekatan yang digunakan oleh Peserta Kajian 5 melaksanakan aktiviti permainan BINGO dalam kumpulan sebagai set induksi (Rajah 6).

Rajah 6: Pendekatan 'chalk and talk'oleh Peserta Kajian 5

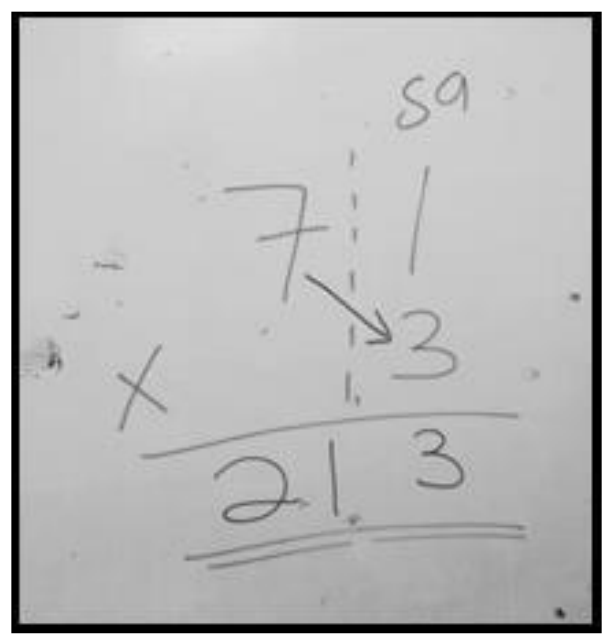

Namun begitu, pengkaji mendapati aktiviti permainan BINGO dalam kumpulan ini bersifat ulang kaji kerana hanya menekankan tentang hafalan pendaraban nombor 1 hingga 6 . Aktiviti ini tidak menjurus ke arah pembelajaran koperatif atau konstruktivisme. Setelah selesai permainan BINGO, Peserta 
DOI: https://doi.org/10.47405/mjssh.v6i12.1181

Kajian 5 menggunakan pendekatan 'chalk and talk' sama seperti Peserta Kajian 4 untuk menerangkan kaedah penyelesaian operasi darab seperti yang ditunjukkan dalam Rajah 6.

Pengkaji turut mendapati murid-murid Peserta Kajian 5 cenderung untuk menghafal prosedur langkah pengiraan operasi darab seperti yang ditunjukkan oleh guru mereka. Ini dapat dilihat daripada Rajah 7 di bawah yang menunjukkan langkah pengiraan oleh seorang murid semasa membuat latihan.

\section{Rajah 7: Langkah Pengiraan Murid}



\section{Pandangan Guru Matematik Sekolah Rendah Terhadap Pendekatan Konseptual Dalam Pengajaran Matematik}

Pengkaji menganalisis pandangan guru matematik sekolah rendah terhadap pendekatan-pendekatan bersifat konseptual dalam pengajaran matematik menggunakan borang kaji selidik berskala likert 5 . Pengkaji mengemukakan 3 pandangan utama iaitu kepentingan pengajaran bersifat konseptual, kebaikan dan kekurangan pendekatan bersifat prosedural dan pelaksanaan pendekatan-pendekatan berkenaan semasa pengajaran dan pembelajaran matematik di dalam atau di luar bilik darjah. Pengiraan secara manual digunakan untuk mengira purata (min) skor bagi setiap item pandangan. Purata skor yang diperoleh bagi setiap jenis pandangan yang diperoleh adalah seperti dalam Jadual 3.

Jadual 3: Min skor bagi ketiga-tiga jenis pandangan guru

\begin{tabular}{lcc}
\hline \multicolumn{1}{c}{ Jenis Pandangan } & Skor Min & Tahap \\
\hline $\begin{array}{l}\text { Mengakui kepentingan } \\
\text { pendekatan-pendekatan bersifat } \\
\text { konseptual }\end{array}$ & 4.08 & Tinggi \\
$\begin{array}{l}\text { Mengakui wujud kebaikan dan } \\
\text { kekurangan pendekatan- } \\
\text { pendekatan bersifat prosedural }\end{array}$ & 3.9 & Tinggi \\
$\begin{array}{l}\text { Sikap terhadap pelaksanaan } \\
\text { pendekatan-pendekatan bersifat } \\
\text { konseptual dan prosedural }\end{array}$ & 3.65 & Sederhana \\
\hline
\end{tabular}

Pecahan purata skor yang diperoleh bagi setiap jenis pandangan berdasarkan item yang diberikan oleh peserta kajian adalah seperti dalam Jadual 4, 5 dan 6. 
Jadual 4: Item dan skor min pandangan guru tentang kepentingan pengajaran bersifat konseptual

\begin{tabular}{clc} 
Bil & \multicolumn{1}{c}{ Item } & Skala \\
\hline 1. & $\begin{array}{l}\text { Pengajaran matematik bersifat konseptual membantu murid menguasai } \\
\text { kaedah menyelesaikan soalan dan seterusnya membantu murid }\end{array}$ & 4.3 \\
mengaplikasikan kaedah tersebut kepada masalah baharu. \\
2. $\begin{array}{l}\text { Apabila murid memahami sesuatu secara relational, matlamat } \\
\text { pembelajaran yang efektif boleh dibentuk hasil daripada pengetahuan yang } \\
\text { bersifat konseptual. }\end{array}$ & 4.5 \\
3. $\begin{array}{l}\text { Sebagai seorang guru matematik, saya mempunyai pengetahuan tentang } \\
\text { pendekatan konstruktivisme, kontekstual, inkuiri penemuan dan } \\
\text { pembelajaran koperatif yang berpusatkan murid. }\end{array}$ & 2.6 \\
$\begin{array}{l}\text { Pengajaran bersifat konseptual wajar dilaksanakan dalam pengajaran dan } \\
\text { pembelajaran matematik. }\end{array}$ & 4.5 \\
Pengajaran matematik bersifat konseptual amat dititikberatkan bagi \\
merealisasikan Pembelajaran Abad Ke-21 (PAK-21).
\end{tabular}

Jadual 5: Item dan skor min pandangan guru tentang kebaikan dan kekurangan pendekatanpendekatan bersifat prosedural

\begin{tabular}{llc} 
Bil & \multicolumn{1}{c}{ Item } & Skala \\
\hline 1. & $\begin{array}{l}\text { Pengajaran bersifat prosedural akan menekankan kepada murid untuk } \\
\text { menghafal kaedah penyelesaian masalah matematik. }\end{array}$ & 4 \\
2. & $\begin{array}{l}\text { Pendekatan bersifat prosedural membolehkan murid menjawab soalan } \\
\text { matematik dengan cepat dan tepat. }\end{array}$ & 3.4 \\
3. & $\begin{array}{l}\text { Kefahaman yang diperoleh murid melalui prosedural berkesan untuk } \\
\text { jangka masa pendek. }\end{array}$ & 4 \\
4. & $\begin{array}{l}\text { Proses pengajaran dan pembelajaran saya tetap mengandungi konsep } \\
\text { kemahiran matematik yang diajar kepada murid walaupun pendekatan } \\
\text { prosedural digunakan. } \quad \text { MIN SKOR }\end{array}$ & 4.2 \\
\hline
\end{tabular}

Jadual 6: Item dan skor min pandangan guru tentang pelaksanaan pendekatan-pendekatan bersifat konseptual dan prosedural

\begin{tabular}{ll} 
Bil & \multicolumn{1}{c}{ Item } \\
1. & $\begin{array}{l}\text { Saya pernah melaksanakan pendekatan konstruktivisme, kontekstual, inkuiri } \\
\text { penemuan, pembelajaran koperatif atau pendekatan lain yang berpusatkan } \\
\text { murid dalam pengajaran dan pembelajaran matematik tetapi menghadapi } \\
\text { pelbagai kekangan. }\end{array}$ \\
2. & $\begin{array}{l}\text { Pengajaran matematik yang memberi fokus kepada penguasaan konsep } \\
\text { sesuatu kemahiran menyebabkan murid sukar memahami dan menjawab } \\
\text { soalan dengan cepat dan betul. }\end{array}$ \\
3. Saya berpendapat pendekatan konseptual dan prosedural wajar diaplikasikan \\
dalam pengajaran dan pembelajaran matematik.
\end{tabular}

MIN SKOR
Skala 


\section{Perbincangan Kajian}

Walaupun 5 orang peserta kajian ini cenderung menggunakan pendekatan prosedural semasa proses pengajaran dan pembelajaran, pengkaji mendapati terdapat beberapa orang peserta kajian menekankan tentang konsep kemahiran matematik yang bersifat pendekatan konseptual semasa memberikan penerangan kepada murid-murid. Hal ini dapat dilihat dalam Rajah 8 di bawah.

\section{Rajah 8: Kemahiran Matematik Yang Bersifat Pendekatan Konseptual}



Rajah 8 di atas menunjukkan contoh pengajaran dan pembelajaran yang dilaksanakan oleh Peserta Kajian 1 tentang konsep pengiraan operasi bergabung. Guru menekankan dalam penerangannya tentang operasi yang perlu diselesaikan terlebih dahulu dalam penyelesaian operasi bergabung.

\section{Rajah 9: Proses Pengajaran dan Pembelajaran Tentang Penyelesaian Pengiraan Darab}

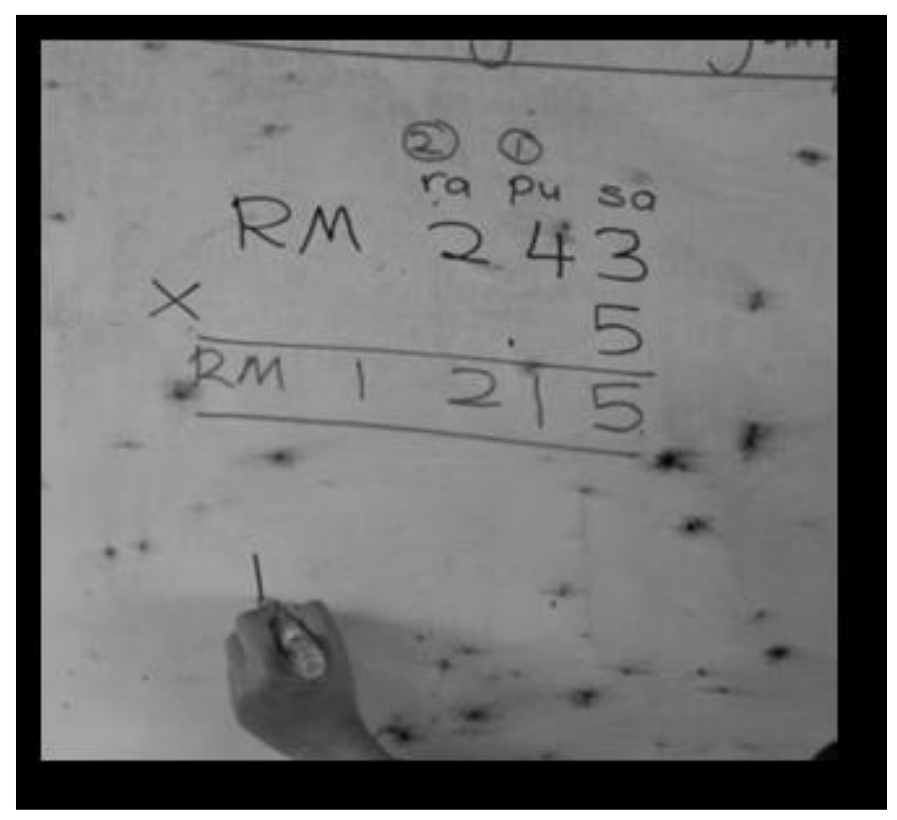

Rajah 9 di atas menunjukkan contoh penerangan Peserta Kajian 4 semasa proses pengajaran dan pembelajaran tentang penyelesaian pengiraan darab dengan cara pengumpulan semula dalam topik Wang. Didapati Peserta Kajian 4 menekankan konsep nilai tempat bagi digit-digit dalam pengiraan 
tersebut. Peserta Kajian 5 dilihat melaksanakan aktiviti permainan BINGO di awal proses pengajaran dan pembelajaran sebagai aktiviti untuk memantapkan penguasaan dan penghafalan sifir. Seterusnya, Peserta Kajian 5 mengaitkan aktiviti tersebut dengan membuat latihan yang melibatkan operasi pendaraban.

Hasil analisis menggunakan borang kaji selidik Skala Likert 5 mata yang telah dijawab oleh kelimalima peserta kajian mendapati mereka sangat bersetuju tahap tinggi (min skor $=4.08)$ akan kepentingan pengajaran bersifat konseptual dan mereka sangat bersetuju tahap tinggi (min skor $=3.9$ ) akan kebaikan dan kekurangan pendekatan bersifat prosedural. Menurut Abdullah (2019), penguasaan konsep matematik yang baik akan memangkinkan murid untuk berfikir dengan aras yang lebih tinggi untuk menyelesaikan masalah matematik. Kajian lepas ini menyokong bahawa 5 orang peserta dalam kajian ini sedar akan kepentingan pengetahuan konseptual mempengaruhi dalam kefahaman dan penguasaan terhadap konsep topik-topik yang terkandung dalam subjek matematik. Pendekatan bersifat prosedural tidak dinafikan mudah untuk diaplikasikan dalam proses pengajaran dan pembelajaran. Hal ini kerana murid akan menghafal kaedah penyelesaian dan berupaya menyelesaikan masalah matematik dengan cepat dan tepat. Namun begitu, kefahaman yang diperoleh adalah bersifat jangka masa pendek.

Seterusnya, kelima-lima peserta kajian ini bersetuju tahap sederhana (min skor $=3.65$ ) akan pelaksanaan pendekatan-pendekatan bersifat konseptual dan prosedural. Dapatan ini menunjukkan mereka kurang berkebolehan untuk mengaplikasikan pendekatan-pendekatan bersifat konseptual semasa proses pengajaran dan pembelajaran. Menurut Nor Adibah binti Abdullah (2020), guru matematik di sekolah cenderung untuk menjawab soalan-soalan ujian secara prosedural iaitu mengaplikasikan peraturan, prosedur dan kiraan semata-mata untuk mendapatkan jawapan sahaja berbanding dengan menjawab secara konseptual. Hal ini kerana guru matematik memberi fokus kepada markah yang akan diperoleh murid semasa pentaksiran. Mereka khuatir kualiti pengajaran dipersoalkan oleh mana-mana pihak dan seterusnya akan mencemarkan reputasi keguruan.

\section{Kesimpulan}

Kajian ini merupakan satu kajian tinjauan dan hanya terhad kepada 5 orang guru matematik sekolah rendah sahaja. Dapatan kajian yang diperoleh boleh dijadikan sebagai panduan ke arah pelaksanaan proses pengajaran dan pembelajaran matematik yang berkesan. Seterusnya, ia juga merupakan salah satu panduan dalam melahirkan guru matematik yang berkualiti tinggi untuk kebaikan murid-murid demi masa depan mereka. Hasil daripada kajian yang telah dijalankan, pengetahuan konseptual wajar dijadikan elemen utama dalam membentuk pengajaran matematik yang berkesan. Pemahaman dan penguasaan konsep matematik yang baik akan membantu murid menyelesaikan masalah matematik dengan tepat dan seterusnya dapat diaplikasikan dalam kehidupan seharian mereka. Kesimpulannya, guru matematik perlu meningkatkan kemahiran mereka dalam melaksanakan pengajaran yang menggunakan pendekatan-pendekatan yang bersifat konseptual.

\section{Rujukan}

Abidin, Z. (2012). Pentingnya pemahaman konseptual dan prosedural dalam belajar matematik. Malang: Universitas Islam Malang.

Adnan, M. dan Zakaria, E. (2012). Pengetahuan konseptual pecahan dalam kalangan bakal guru matematik. Jurnal Pendidikan Sains \& Matematik Malaysia, 2(1). 12-22.

Abdullah, N.A. (2019). Mathematics Teachers' Conceptual Knowledge of Algebra: A Literature Review/ Pengetahuan Konseptual Algebra Guru Matematik: Satu Kajian Literatur. Sains Humanika, 12(1): 19-30.

Adnan, M. (2014). Aplikasi model persamaan berstruktur dalam menilai kepercayaan dan pengetahuan konseptual guru matematik sekolah rendah 2(1): 32-50. 
DOI: https://doi.org/10.47405/mjssh.v6i12.1181

Fallis, A.. (2013). Persepsi dan sikap pelajar terhadap pendekatan konstruktivisme serta kesan terhadap pencapaian dalam mata pelajaran Matematik di Fakulti Pendidikan Universiti Teknologi Malaysia. Journal of Chemical Information and Modeling, 53(9): 1689-1699.

Kurikulum, B.P. (2019). Matematik. Dokumen Standard Kurikulum Dan Pentaksiran Tahun 5.

Leong, T.G. ... Idrus, M. (2020). Analisis keperluan bagi pembangunan modul matematik tingkatan 1 untuk pengekalan pengetahuan konseptual dan prosedural 8(2): 86-99.

Mohd Rusdin, N. \& Dollah, M.U. (2018). Keupayaan menyelesaikan masalah matematik berayat menggunakan strategi melukis gambar rajah dalam kalangan murid tahun 3 Sekolah Rendah. Jurnal Pendidikan Sains Dan Matematik Malaysia, 8(2): 74-85.

Mulyono, B. ... Konsep, P. (2018). Pemahaman konsep dalam pembelajaran matematika 3(2): 103122.

Nor Adibah binti Abdullah. (2020). Kompetensi penyelesaian masalah dan pengetahuan konseptual guru matematik sekolah menengah. Jurnal Kurikulum \& Pengajaran Asia Pasifik, 8(3): 1-14.

Salleh, I. (2016). Pedagogi matematik sekolah rendah: Konseptual atau prosedural. Ds.

Talib, A. (2017). Analisis pemahaman konseptual dan prosedural siswa dalam menyelesaikan soal matematik berdasarkan gaya belajar 1(2): 101-106.

Tengku Zainal, Tengku Zawawi; Mustapha, Ramlee; Habib, A.R. (2009). Pengetahuan pedagogi isi kandungan guru matematik bagi tajuk pecahan: Kajian kes di sekolah rendah 34(1): 131-153.

Yahaya, A. (2018). Kepentingan faham konsep mat. Isu-Isu Pendidikan Sains Dan Matematik.

Yusof, Y. ... Sern, L.C. (2016). Integrasi konsep dan teori beban kognitif dalam pendidikan kejuruteraan di Malaysia: satu kajian literatur. Geografia - Malaysian Journal of Society and Space, 12(3): 46-57.

Zainal Abidin Bin Zainuddin, A.B.S. (2008). Keberkesanan kaedah konstruktivisme dalam pengajaran dan pembelajaran matematik. Fakulti Pendidikan, Universiti Teknologi Malaysia Diperoleh pada 12 November 2015. 